Jurnal Agro 8(1), 2021

\title{
PENGARUH PUPUK GUANO DAN MEDIA TANAM TERHADAP PERTUMBUHAN DAN HASIL TANAMAN BUNCIS TEGAK
}

\author{
The Effect of Guano Fertilizer and Growing Media on Growth and Yield of Bush Bean
}

\author{
Esty Puri Utami*, Indri Heryani, Liberty Chaidir \\ Jurusan Agroteknologi Fakultas Sains dan Teknologi UIN Sunan Gunung Djati Bandung. \\ Jl. A. H. Nasution No. 105, Cipadung, Kec. Cibiru, Kota Bandung, Jawa Barat 40614.
}

Korespondesi: estypuriutami@uinsgd.ac.id

Diterima : 26 November 2020 / Disetujui : 19 Juli 2021

\begin{abstract}
ABSTRAK
Penurunan kualitas tanah karena akumulasi penggunaan pupuk kimia berdampak pada penurunan hasil tanaman buncis tegak. Teknik budidaya organik dengan menggunakan media tanam campuran tanah, arang sekam, dan cocopeat serta penggunaan pupuk guano dilakukan sebagai upaya alternatif peningkatan produksi buncis. Penelitian ini bertujuan untuk mengkaji pengaruh dosis pupuk guano dan berbagai jenis media tanam terhadap pertumbuhan dan hasil tanaman buncis tegak (Phaseolus vulgaris L.). Penelitian dilaksanakan dari April hingga Mei 2020 di Desa Cileunyi Kulon, Kecamatan Cileunyi, Kabupaten Bandung. Rancangan percobaan berupa Rancangan Acak Kelompok (RAK) faktorial dua faktor. Faktor pertama yaitu dosis pupuk guano terdiri atas 4 taraf: kontrol, $5 \mathrm{t} \mathrm{ha}^{-1}, 10 \mathrm{t} \mathrm{ha}^{-1}$, dan $15 \mathrm{t} \mathrm{ha}^{-1}$. Faktor kedua yaitu media tanam dengan 5 taraf: tanah (kontrol), arang sekam padi, cocopeat, tanah + arang sekam padi, dan tanah + cocopeat. Hasil penelitian menunjukkan interaksi antara dosis pupuk guano dengan media tanam pada tinggi tanaman 28 HST. Dosis pupuk guano berkorelasi positif dengan variabel pertumbuhan tanaman dengan dosis terbaik yaitu $15 \mathrm{t} \mathrm{ha}^{-1}$. Media tanam campuran tanah dan arang sekam menghasilkan tanaman dengan tinggi tanaman, bobot polong segar, dan bobot polong kering tertinggi di antara semua perlakuan. Pupuk guano dapat di aplikasikan pada berbagai media tanam untuk menghasilkan pertumbuhan tanaman buncis yang optimal.
\end{abstract}

Kata Kunci: Arang sekam, Cocopeat, Guano, Media tanam, Pupuk Organik, Tanah

\begin{abstract}
The decline in soil quality cause by chemical fertilizer affected to the growth and yield of bush bean. Organic farming using guano fertilizer and combination of soil, husk charcoal, and cocopeat as the planting media can be used as an alternative technology to increase bush bean production. This study aimed to determine the effect of guano fertilizer dosage and various type of growing media on growth and yield of bush bean (Phaseolus vulgaris L.). This study was conducted from April to May 2020 at Cikandang village, Cileunyi Kulon, Cileunyi, Bandung. The experimental design used was factorial randomized block design with two factors. The first factor was dosage of guano fertilizer consisted of 4 levels i.e. control, $5 \mathrm{t} \mathrm{ha}^{-1}, 10 \mathrm{t} \mathrm{ha}^{-1}$, and $15 \mathrm{t}$ $\mathrm{ha}^{-1}$. The second factor was growing media with 5 levels i.e. soil (control), husk charcoal, cocopeat, soil + husk charcoal, and soil + cocopeat. The results showed the interaction between
\end{abstract}

Cite this as: Utami E P., Heryani I. \& Chaidir L. (2021). Pengaruh pupuk guano dan media tanam terhadap pertumbuhan dan hasil tanaman buncis tegak. Jurnal Agro, 8(1), 100-112. 
dosage of guano fertilizer and growing media on plant height in 28 days after planting. The dosage of guano fertilizer had a positive correlation with plant growth traits, and $15 \mathrm{t} \mathrm{ha}^{-1}$ as the best dosage for bush bean growth and yield. The media soil + husk charcoal produced plants with the highest plant height, fresh pod weight, and dry pod weight among all treatments. Guano fertilizer can be applied to various growing media to produce the optimal bush bean growth.

Keywords: Cocopeat, Guano, Husk Charcoal, Organic Fertilizer, Soil

\section{PENDAHULUAN}

Buncis (Phaseolus vulgaris L.) merupakan salah satu tanaman Leguminous yang memiliki kandungan protein yang tinggi dan asam amino essensial yang dianggap sebagai sumber gizi bagi masyarakat. Buncis digolongkan menjadi dua jenis sesuai dengan tipe pertumbuhannya, yaitu buncis tegak dan buncis merambat.

Data produksi buncis nasional dari Badan Pusat Statistik (2019) menunjukkan bahwa pada tahun 2015 produksi buncis mencapai 291.333 t. Pada tahun 2016, produksi mengalami penurunan menjadi $275.535 \mathrm{t}$. Produksi buncis kembali meningkat pada tahun 2017 dan 2018 menjadi 279.040 t dan $304.445 \mathrm{t}$, tetapi kembali menurun pada tahun 2019 menjadi 299.311 t. Ketidakstabilan produksi buncis ini salah satu penyebabnya ialah penurunan kualitas tanah akibat akumulasi dari penggunaan pupuk anorganik yang terus menerus.

Penggunaan pupuk anorganik yang berlebihan dapat menurunkan kandungan bahan organik dalam tanah yang kemudian menyebabkan penurunan kualitas tanah (Sari et al., 2017). Mikroba tanah menguraikan bahan organik. Apabila tidak ada bahan organik, mikroba dalam tanah menjadi tidak efektif dalam bekerja, penguraian residu kimia tanah menjadi terganggu. Hal ini berakibat pada mengerasnya tanah, apabila tanah mengeras, aerasi dan sirkulasi tanah menjadi terhambat (Bintara et al., 2017). Kondisi ini menyebabkan pertumbuhan tanaman juga akan terhambat. Budidaya tanaman secara organik dapat menjadi alternatif usaha peningkatan produksi buncis yang ramah lingkungan. Penggunaan pupuk organik dapat meningkatkan kandungan bahan organik dalam tanah.

Pupuk guano, salah satu pupuk organik, dapat memperbaiki kesuburan tanah dan memiliki kandungan $\mathrm{N}, \mathrm{P}$, dan $\mathrm{K}$ yang tinggi sehingga dapat meningkatkan pertumbuhan dan hasil tanaman buncis (Syofiani \& Oktabriana, 2017). Penggunaan pupuk guano harus memperhatikan dosis yang optimum bagi tanaman. Pemberian pupuk organik berpengaruh terhadap sifat fisik tanah. Pemberian dosis pupuk guano $10 \mathrm{t} \mathrm{ha}^{-1}$ menyebabkan penurunan suhu tanah (dari $30,91^{\circ} \mathrm{C}$ pada 15 hari setelah tanam (HST) menjadi $28,55^{\circ} \mathrm{C}$ pada $60 \mathrm{HST}$, persentase kadar lengas tertinggi $(17,62 \%)$ dan penurunan $\mathrm{pH}$ tanah menjadi netral $(\mathrm{pH}$ 8,12). Dosis ini menyebabkan kondisi lingkungan menjadi optimum bagi kacang merah, sehingga pertumbuhan kacang merah pun lebih tinggi dibandingkan kontrol dan dosis $5 \mathrm{t} \mathrm{ha}^{-1}$. Dosis $10 \mathrm{t} \mathrm{ha}^{-1}$ menghasilkan tinggi tanaman tertinggi, yaitu 33,44 cm (kontrol 20,95 cm dan 5 t ha $128,66 \mathrm{~cm}$ ) dan jumlah daun terbanyak, yaitu 39,30 helai (kontrol 23,02 helai dan 5 $\mathrm{t} \mathrm{ha}^{-1} 27,19$ helai) (Naben \& Raharjo, 2017). 
Dosis pupuk guano $10 \mathrm{t} \mathrm{ha}^{-1}$ yang diberikan pada tanaman mentimun juga merupakan dosis terbaik dalam memberikan hasil tertinggi untuk variabel pengamatan tinggi tanaman, jumlah daun, dan jumlah polong. Dosis optimum pupuk guano berbeda untuk setiap tanaman. Pada tanaman kacang tanah, pemberian pupuk guano $15 \mathrm{t} \mathrm{ha}^{-1}$ mampu meningkatkan hasil panen tanaman kacang tanah (Isrun, 2009).

Selain pemupukan, media tanam juga merupakan faktor penting untuk meningkatkan pertumbuhan dan hasil tanaman buncis. Penggunaan cocopeat dan arang sekam sebagai media tanam dapat meningkatkan jumlah ketersediaan bahan organik. Arang sekam kaya akan kandungan karbon (C) yang tinggi serta cocopeat kaya akan kalium (K) disamping unsur hara lainnya. Arang sekam dan cocopeat masih jarang digunakan sebagai media tanam padahal ketersediaan bahan baku kedua media tanam tersebut sangat berlimpah (Suswati et al., 2015).

Pemberian pupuk guano $5 \mathrm{t} \mathrm{ha}^{-1}$ dan arang sekam $5 \mathrm{t} \mathrm{ha}^{-1}$ sebagai media tanam pada tanaman kacang hijau menghasilkan tanaman tertinggi dengan batang yang lebih besar dan jumlah daun lebih banyak. Pada perlakuan ini menunjukkan kadar lengas tanah lebih tinggi, pH tanah netral $(7,65)$ dan DHL lebih tinggi (1041,33 s) yang menunjukkan tersedianya unsur hara cukup dalam media tanam yang terdiri dari tanah, arang sekam dan pupuk guano bagi kebutuhan tanaman (Taek, 2016).

Penambahan pupuk guano pada media tanam diharapkan dapat menambah jumlah unsur hara, khususnya $P$, pada media tanam. Namun, perlu dipelajari lebih lanjut dosis pupuk guano yang optimum termasuk untuk pertumbuhan tanaman buncis. Pengaruh penggunaan pupuk guano dan media tanam arang sekam dan cocopeat pada tanaman buncis belum banyak dilakukan. Pemberian pupuk guano juga harus sesuai dengan dosis yang diperlukan oleh tanaman buncis untuk memenuhi kebutuhan unsur hara tanaman. Oleh karena itu, penelitian ini bertujuan untuk mengetahui pengaruh dosis pupuk guano dan kombinasi media tanam tanah, arang sekam dan cocopeat terhadap pertumbuhan dan hasil tanaman buncis tegak (Phaseolus vulgaris L.).

\section{BAHAN DAN METODE}

Penelitian dilaksanakan dari bulan April sampai Mei 2020 bertempat di Kp. Cikandang, Desa Cileunyi Kulon, Kecamatan Cileunyi, Kabupaten Bandung. Secara geografis wilayah kecamatan ini berada pada ketinggian $780 \mathrm{mdpl}$.

Bahan tanam yang digunakan yaitu benih buncis varietas Kenya. Metode penelitian menggunakan metode eksperimen dan rancangan percobaannya menggunakan rancangan acak kelompok faktorial dua faktor. Faktor yang pertama dosis pupuk Nafos Guano ( $g_{0}$ : Kontrol, $g_{1}: 5$ $\left.\mathrm{t} \mathrm{ha}^{-1}, \mathrm{~g}_{2}: 10 \mathrm{t} \mathrm{ha}^{-1}, \mathrm{~g}_{3}: 15 \mathrm{t} \mathrm{ha}^{-1}\right)$. Faktor yang kedua media tanam $\left(\mathrm{m}_{0}\right.$ : tanah (kontrol), $m_{1}$ : arang sekam padi, $m_{2}$ : cocopeat, $m_{3}$ : tanah dan arang sekam padi (dengan perbandingan 1:1 $(\mathrm{v} / \mathrm{v})), \mathrm{m}_{4}$ : tanah dan cocopeat (dengan perbandingan 1:1 (v/v)). Setiap perlakuan diulang sebanyak 3 kali, sehingga diperoleh 60 satuan percobaan.

Pengamatan dilakukan terhadap tinggi tanaman $(\mathrm{cm})$, luas daun $\left(\mathrm{cm}^{2}\right)$, bobot polong segar (g), berat polong (g) dan indeks panen. Data hasil pengamatan dianalisis menggunakan analisis ragam. Hasil analisis ragam yang signifikan kemudian diuji lanjut menggunakan uji 
lanjut Duncan Multiple Range Test (DMRT) pada taraf signifikan 5\%. Pengamatan penunjang selama penelitian adalah pengukuran suhu dan kelembaban, $\mathrm{pH}$ tanah dan hama dan penyakit.

Media tanam yang sudah disiapkan dimasukkan ke dalam polybag berukuran 30 $\mathrm{cm} \times 35 \mathrm{~cm}$. Pengaplikasian pupuk guano dilakukan tujuh hari sebelum penanaman dengan cara mencampurkan pupuk Nafos Guano sesuai dosis perlakuan dengan media tanam. Penyulaman dilakukan pada 7 HST.

Pengajiran dilakukan dengan menggunakan bambu dengan tinggi $70 \mathrm{~cm}$ yang dipasang pada saat tanaman berumur 10 HST pada polibag. Ajir dipasang dengan jarak $5 \mathrm{~cm}$ dari tanaman buncis dengan kedalaman minimum $10 \mathrm{~cm}$. Penyiangan dilakukan dengan cara membersihkan area tanaman pada polybag dari gulma. Penyiangan ini dilakukan mulai umur 7 HST dengan mencabut gulma secara manual menggunakan tangan. Panen pertama dilakukan saat tanaman mencapai umur 45 HST. Panen selanjutnya dilakukan setiap 5 hari sekali. Pemanenan dilakukan sebanyak 4 kali.

\section{HASIL DAN PEMBAHASAN}

\section{Kondisi Umum}

Derajat kemasaman tanah pada tempat penelitian menunjukkan bahwa tanah memilki pH 6 (netral). Rata-rata suhu harian pada saat penelitian yaitu $26,82^{\circ} \mathrm{C}$, suhu maksimum $35^{\circ} \mathrm{C}$ dan suhu minimum mencapai $23{ }^{\circ} \mathrm{C}$. Rata-rata kelembaban harian yaitu $81,09 \%$.

Derajat kemasaman tanah yang optimum untuk tanaman buncis berkisar antara 5,8-6,0. Pada $\mathrm{pH}$ tersebut tanaman buncis dapat beradaptasi dengan baik sehingga tanaman buncis dapat tumbuh (Djuariah et al., 2016). Tanaman buncis varietas Kenya memiliki syarat tumbuh di suhu 20-25 ${ }^{\circ} \mathrm{C}$ dan kelembaban yang diperlukan tanaman buncis sekitar $50-60 \%$. Suhu pada tempat penelitian tergolong panas jika dibandingkan dengan syarat tumbuh. Berdasarkan hasil uji laboratorium, pupuk Nafos Guano memiliki kadar hara $\mathrm{P}_{2} \mathrm{O}_{5}$ Total 22-26\%, $\mathrm{CaO} 35-40 \%, \mathrm{SiO}_{2} 8,8 \%$, $\mathrm{Fe}_{2} \mathrm{O}_{3}$ 1,6\%, TiO 0,008\%, $\mathrm{Al}_{2} \mathrm{O}_{3}$ 15,9\%, MgO $1,09 \%$ (Syofiani \& Oktabriana, 2017).

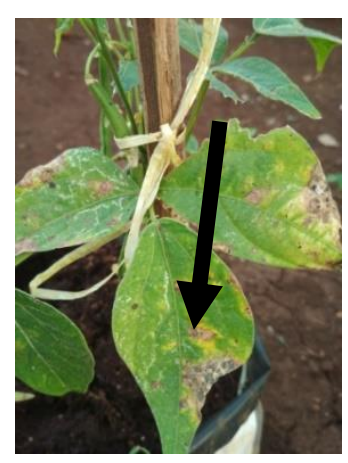

Gambar 1. Penyakit karat daun pada tanaman buncis

Hama dan penyakit yang menyerang tanaman buncis Kenya selama penelitian yaitu kutu kebul (Bemisia tabaci Genn.), ulat polong (Etiella zinckenella T.) dan karat daun. Serangan kutu kebul terjadi pada saat fase vegetatif yaitu ketika tanaman berumur 10 HST. Organisme Penggangu Tanaman (OPT) selanjutnya yaitu ulat polong (Etiella zinckenella T.) kebanyakan terjadi saat fase generatif. Pengendalian dengan penyemprotan insektisida berbahan aktif deltametrin $\left(25 \mathrm{~g} \mathrm{l}^{-1}\right)$ pada tanaman berumur 29 HST hingga 31 HST. Penyemprotan insektisida dilakukan pada pagi hari. Intensitas serangan kedua hama ini hanya berkisar $5 \%$. Hama tanaman yang menyerang berangsur-angsur menghilang 
setelah dilakukan pengendalian. Adapun penyakit yang menyerang tanaman buncis Kenya yaitu karat daun (Gambar 1). Gejalanya terlihat pada permukaan daun terdapat bintik-bintik kecil berwarna coklat tua, kemudian bintik-bintik tersebut menyebar pada permukaan atas dan bawah daun dengan bentuk yang bervariasi.

\section{Tinggi Tanaman}

Pengamatan tinggi tanaman dilakukan pada 7 HST, 14 HST, 21 HST dan 28 HST. Tabel 1 menunjukkan tidak terdapat interaksi antara perlakuan pupuk guano dengan media tanam. Pada 7 dan 14 HST, pengaruh pupuk guano belum terlihat pada tanaman buncis, namun pada umur $21 \mathrm{HST}$, perlakuan pemberian pupuk guano $15 \mathrm{t}$ ha1 mampu menghasilkan rerata tertinggi untuk pengamatan tinggi tanaman.

Pengaruh interaksi pupuk Nafos Guano dan media tanam terlihat pada tinggi tanaman umur 28 HST. Kombinasi perlakuan pupuk guano dengan dosis $15 \mathrm{t}$ ha-1 dan campuran media tanam tanah dan arang sekam memberikan hasil rerata tinggi tanaman tertinggi dibandingkan perlakuan lainnya (Tabel 2).

Tabel 1. Pengaruh Pupuk Nafos Guano dan Media Tanam terhadap Tinggi Tanaman Buncis Kenya pada 7, 14 dan 21 HST.

\begin{tabular}{lccc}
\hline \multirow{2}{*}{ Perlakuan } & \multicolumn{3}{c}{ Rata-rata Tinggi Tanaman (cm) } \\
\cline { 2 - 4 } Nafos Guano & $7 \mathrm{HST}$ & $14 \mathrm{HST}$ & $21 \mathrm{HST}$ \\
$\mathrm{g}_{0}\left(0 \mathrm{t} \mathrm{ha}^{-1}\right)$ & $7,57 \mathrm{a}$ & $10,79 \mathrm{a}$ & $17,29 \mathrm{a}$ \\
$\mathrm{g}_{1}\left(5 \mathrm{t} \mathrm{ha}^{-1}\right)$ & $7,84 \mathrm{a}$ & $10,96 \mathrm{a}$ & $18,23 \mathrm{a}$ \\
$\mathrm{g}_{2}\left(10 \mathrm{t} \mathrm{ha}^{-1}\right)$ & $7,68 \mathrm{a}$ & $11,15 \mathrm{a}$ & $18,29 \mathrm{ab}$ \\
$\mathrm{g}_{3}\left(15 \mathrm{t} \mathrm{ha}^{-1}\right)$ & $8,01 \mathrm{a}$ & $11,35 \mathrm{a}$ & $19,31 \mathrm{~b}$ \\
\hline Media Tanam & & & \\
$\mathrm{m}_{0}$ (Kontrol) & $7,65 \mathrm{a}$ & $11,00 \mathrm{a}$ & $18,21 \mathrm{a}$ \\
$\mathrm{m}_{1}$ (Arang sekam padi) & $7,82 \mathrm{a}$ & $10,84 \mathrm{a}$ & $17,52 \mathrm{a}$ \\
$\mathrm{m}_{2}$ (Cocopeat) & $7,75 \mathrm{a}$ & $10,61 \mathrm{a}$ & $17,02 \mathrm{a}$ \\
$\mathrm{m}_{3}$ (Tanah+Arang sekam) & $7,82 \mathrm{a}$ & $11,61 \mathrm{~b}$ & $19,66 \mathrm{c}$ \\
$\mathrm{m}_{4}$ (Tanah+Cocopeat) & $7,84 \mathrm{a}$ & $11,24 \mathrm{ab}$ & $19,01 \mathrm{~b}$ \\
\hline Ketrangan: Anganga & & & \\
\hline
\end{tabular}

Keterangan: Angka-angka yang diikuti oleh huruf yang sama pada kolom yang sama menunjukkan tidak berbeda nyata berdasarkan Uji Lanjut Duncan pada taraf $5 \%$.

Media tanam campuran tanah dan arang sekam memiliki sifat porositas yang baik untuk menunjang pertumbuhan tanaman buncis Kenya. Porositas arang sekam mencapai $46 \%$, artinya dalam $100 \mathrm{ml}$ arang sekam, $46 \mathrm{ml}$ nya terisi oleh air ataupun udara (Drupadi \& Suhardiyanto, 2016). Keberadaan air sangat menunjang pertumbuhan tanaman, terutama tinggi tanaman. Tinggi tanaman merupakan variabel pengamatan yang sangat sensitif terhadap keberadaan air. Umumnya tanaman yang kekurangan air akan lebih pendek daripada tanaman yang cukup air (Sitompul, 2016). Tanaman buncis menunjukkan respon yang sensitif terhadap 
kekurangan air. Pemberian air sebesar 50\% dari kapasitas lapang media tanam tanah+ arang sekam pada fase vegetatif dan generatif menurunkan pertumbuhan tanaman, khususnya untuk tinggi dan jumlah daun (Marsha et al., 2015).

Campuran media tanam tanah+arang sekam sangat bagus sebagai bahan campuran pupuk organik karena arang sekam dapat memperbaiki porositas media tanam. Arang sekam memiliki struktur yang lebih remah dibandingkan dengan cocopeat, sehingga akar tanaman dapat berkembang dengan baik. Apabila pertumbuhan akar tidak terganggu, maka akar akan lebih mudah untuk menyerap air dan hara yang kemudian akan ditranslokasikan ke titik tumbuh lainnya (Irawan \& Kafiar, 2015).

Interaksi antara pupuk guano dengan media tanam memberikan pertumbuhan pucuk yang cepat. Pupuk guano meningkatkan unsur hara media tanam, terutama unsur $\mathrm{CaO}$ yang dapat menaikan $\mathrm{pH}$ tanah serta meningkatkan ketersediaan hara lain yang sukar larut seperti pupuk $\mathrm{P}_{2} \mathrm{O}_{5}$ yang dimiliki oleh pupuk guano.

Pengaruh interaksi antara perlakuan pupuk Nafos Guano dengan media tanaman hanya terlihat pada tinggi tanaman umur 28 HST. Hal ini diduga disebabkan karena campuran media tanam tanah dan arang sekam mampu menyimpan hara dan nutrisi bagi pertumbuhan tanaman dan baru nampak pengaruhnya pada umur $28 \mathrm{HST}$, sehingga pertumbuhan tinggi di 28 HST mencapai tinggi yang maksimum dibandingkan dengan interaksi perlakuan lainnya. Selain itu, variabel pengamatan lainnya tidak dilakukan secara berulang setiap minggu. Oleh karena itu, pengaruh interaksi belum terlihat pada variabel pengamatan lainnya.

Tabel 2. Pengaruh Pupuk Nafos Guano dan Media Tanam Terhadap Tinggi Tanaman Pada 28 HST

\begin{tabular}{cccccc}
\hline & \multicolumn{5}{c}{ Rata-rata Tinggi Tanaman $(\mathrm{cm})$} \\
\cline { 2 - 6 } Perlakuan & $\mathrm{m}_{0}($ Tanah) & $\begin{array}{c}\mathrm{m}_{1}(\text { Arang } \\
\text { sekam) }\end{array}$ & $\begin{array}{c}\mathrm{m}_{2} \\
\text { (Cocopeat) }\end{array}$ & $\begin{array}{c}\mathrm{m}_{3} \\
\text { (Tanah+arang } \\
\text { sekam) }\end{array}$ & $\begin{array}{c}\mathrm{m}_{4} \text { (Tanah+ } \\
\text { cocopeat) }\end{array}$ \\
\hline $\mathrm{g}_{0}\left(0 \mathrm{t} \mathrm{ha}^{-1}\right)$ & $25,07 \mathrm{a}$ & $21,67 \mathrm{a}$ & $24,57 \mathrm{a}$ & $26,40 \mathrm{a}$ & $25,27 \mathrm{a}$ \\
& $\mathrm{BC}$ & $\mathrm{A}$ & $\mathrm{B}$ & $\mathrm{D}$ & $\mathrm{C}$ \\
$\mathrm{g}_{1}\left(5 \mathrm{t} \mathrm{ha}^{-1}\right)$ & $26,13 \mathrm{a}$ & $24,30 \mathrm{~b}$ & $21,77 \mathrm{a}$ & $27,07 \mathrm{a}$ & $26,73 \mathrm{a}$ \\
& $\mathrm{BC}$ & $\mathrm{B}$ & $\mathrm{A}$ & $\mathrm{D}$ & $\mathrm{C}$ \\
$\mathrm{g}_{2}\left(10 \mathrm{t} \mathrm{ha}^{-1}\right)$ & $26,27 \mathrm{a}$ & $24,27 \mathrm{bc}$ & $22,83 \mathrm{~b}$ & $28,33 \mathrm{a}$ & $28,70 \mathrm{a}$ \\
$\mathrm{g}_{3}\left(15 \mathrm{t} \mathrm{ha}^{-1}\right)$ & $\mathrm{B}$ & $\mathrm{A}$ & $\mathrm{A}$ & $\mathrm{C}$ & $\mathrm{D}$ \\
& $27,33 \mathrm{a}$ & $25,10 \mathrm{c}$ & $24,57 \mathrm{~b}$ & $29,70 \mathrm{~b}$ & $27,23 \mathrm{a}$ \\
& $\mathrm{B}$ & $\mathrm{A}$ & $\mathrm{A}$ & $\mathrm{C}$ & $\mathrm{B}$ \\
\hline
\end{tabular}

Keterangan: Angka rata-rata yang diikuti huruf yang sama (huruf kecil arah vertikal dan huruf besar arah horizontal) menunjukkan tidak berbeda nyata menurut Uji Jarak Berganda Duncan pada taraf $5 \%$.

\section{Luas Daun}

Tabel 3 menunjukkan bahwa pemberian pupuk Nafos guano secara mandiri berpengaruh terhadap luas daun. Luas daun buncis dengan perlakuan $\mathrm{g}_{3}\left(15 \mathrm{t} \mathrm{ha}^{-1}\right)$ menunjukkan perbedaan yang nyata dengan perlakuan lainnya. Penelitian dengan perlakuan dosis pupuk guano $15 \mathrm{t}$ 
ha $^{-1}$ pada tanaman jagung menghasilkan luas daun yang tertinggi dibandingkan dosis yang lebih rendah (Hariyadi, 2018). Hal ini diduga karena pada peningkatan dosis pupuk guano mampu meningkatkan unsur hara baik mikro maupun makro. menyebutkan bahwa hara tersebut kemudian ditranslokasikan oleh tanaman untuk proses metabolisme, yang selanjutnya akan menghasilkan pertambahan luas daun.

Pupuk guano memiliki kandungan unsur hara $\mathrm{P}_{2} \mathrm{O}_{5}$ yang cukup tinggi (Syofiani \& Oktabriana, 2017), dimana unsur hara $P$ diperlukan dalam pembentukan gula fosfat yang dibutuhkan tanaman pada saat tanaman melakukan proses fotosintesis (Hariyadi, 2018). Apabila fotosintesis berjalan dengan baik, maka fotosintat semakin banyak dan pertumbuhan serta perkembangan tanaman semakin meningkat (Ernawati et al., 2018). Hal ini sesuai dengan pendapat (Lakitan, 2010), bahwa akar, batang dan daun merupakan bagian tanaman yang memanfaatkan banyak fotosintat selama fase vegetatif. Apabila unsur hara cukup dan seimbang selama pertumbuhan tanaman, maka pertumbuhan tanaman, dalam hal ini luas daun, akan melebar.

Tabel 3. Pengaruh Pupuk Nafos Guano dan Media Tanam terhadap Luas Daun

\begin{tabular}{lc}
\hline Perlakuan & Rata-rata Luas Daun $\left(\mathrm{cm}^{2}\right)$ \\
\hline Nafos Guano & $--\mathrm{cm}^{2}--$ \\
$\mathrm{g}_{0}\left(0 \mathrm{t} \mathrm{ha}^{-1}\right)$ & $154,87 \mathrm{a}$ \\
$\mathrm{g}_{1}\left(5 \mathrm{t} \mathrm{ha}^{-1}\right)$ & $167,23 \mathrm{a}$ \\
$\mathrm{g}_{2}\left(10 \mathrm{t} \mathrm{ha}^{-1}\right)$ & $188,49 \mathrm{a}$ \\
$\mathrm{g}_{3}\left(15 \mathrm{t} \mathrm{ha}^{-1}\right)$ & $206,81 \mathrm{~b}$ \\
\hline Media Tanam & \\
$\mathrm{m}_{0}$ (Kontrol) & $189,49 \mathrm{a}$ \\
$\mathrm{m}_{1}$ (Arang sekam padi) & $183,68 \mathrm{a}$ \\
$\mathrm{m}_{2}$ (Cocopeat) & $161,75 \mathrm{a}$ \\
$\mathrm{m}_{3}$ (Tanah+Arang sekam) & $168,82 \mathrm{a}$ \\
$\mathrm{m}_{4}$ (Tanah+Cocopeat) & $193,01 \mathrm{a}$ \\
\hline
\end{tabular}

Keterangan: Angka rata-rata yang diikuti oleh huruf yang sama pada kolom yang sama menunjukkan tidak berbeda nyata berdasarkan Uji Lanjut Duncan pada taraf 5\%.

\section{Bobot Polong Segar}

Tabel 4 menunjukkan bahwa tidak terjadi interaksi antara perlakuan pupuk Nafos Guano dan media tanam terhadap bobot polong segar. Pengaruh mandiri dari pupuk Nafos Guano terlihat bahwa perlakuan $\mathrm{g}_{3}\left(15 \mathrm{t} \mathrm{ha}^{-1}\right)$ menghasilkan bobot polong segar tertinggi diantara dosis lainnya.
Berat polong segar merupakan hasil pertumbuhan fase generatif, hal ini tentu saja dipengaruhi oleh jumlah fotosintat yang dihasilkan tanaman termasuk pada fase vegetatif. Jumlah fotosintat yang dihasilkan sangat dipengaruhi luas daun karena proses fotosintesis terutama berlangsung pada daun (Tabel 3). Pada 
parameter luas daun, perlakuan dosis pupuk Nafos Guano $15 \mathrm{t} \mathrm{ha}^{-1}$ memberikan hasil luas daun tertinggi, sehingga pada perlakuan yang sama bobot polong segarnya pun lebih tinggi. Daun yang permukaannya lebih luas memungkinkan memiliki klorofil yang lebih banyak, menangkap cahaya matahari lebih efisien, sehingga proses fotosintesis menghasilkan fotosintat yang lebih banyak. Nilai koefisien korelasi luas daun dan bobot polong segar, yaitu 0,97 (Tabel 7) dan grafiknya menunjukkan hubungan yang linier positif. Hal ini menunjukkan bahwa besarnya luas daun sangat mempengaruhi bobot polong segar yang dihasilkan (Gambar 2).

Tabel 4. Pengaruh Pupuk Guano dan Media Tanam terhadap Bobot Polong Segar

\begin{tabular}{lc}
\hline \multicolumn{1}{c}{ Perlakuan } & Rata-rata Bobot Polong Segar $(\mathrm{g})$ \\
\hline Nafos Guano & \\
$\mathrm{g}_{0}$ (Kontrol) & $11,00 \mathrm{a}$ \\
$\mathrm{g}_{1}$ (Guano $\left.5 \mathrm{t} \mathrm{ha}^{-1}\right)$ & $11,87 \mathrm{a}$ \\
$\mathrm{g}_{2}\left(\right.$ Guano $\left.10 \mathrm{t} \mathrm{ha}^{-1}\right)$ & $12,98 \mathrm{~b}$ \\
$\mathrm{~g}_{3}$ (Guano $\left.15 \mathrm{t} \mathrm{ha}^{-1}\right)$ & $15,62 \mathrm{c}$ \\
\hline Media Tanam & \\
$\mathrm{m}_{0}$ (Kontrol) & $14,03 \mathrm{c}$ \\
$\mathrm{m}_{1}$ (Arang sekam padi) & $10,29 \mathrm{a}$ \\
$\mathrm{m}_{2}$ (Cocopeat) & $9,01 \mathrm{a}$ \\
$\mathrm{m}_{3}$ (Tanah+Arang sekam) & $18,59 \mathrm{~d}$ \\
$\mathrm{~m}_{4}$ (Tanah+Cocopeat) & $12,42 \mathrm{~b}$ \\
\hline
\end{tabular}

Keterangan: Angka rata-rata yang diikuti oleh huruf yang sama pada kolom yang sama menunjukkan tidak berbeda nyata berdasarkan Uji Lanjut Duncan pada taraf $5 \%$.

Media tanam campuran tanah+arang sekam memberikan hasil bobot polong segar tertinggi karena penambahan arang sekam pada media tanah mampu meningkatkan porositas media (Drupadi \& Suhardiyanto, 2016), sehingga akar tanaman dapat menyerap unsur hara lebih maksimal. Hasil penelitian yang menggunakan media tanah+arang sekam dengan perbandingan 1:1 sebagai media tanam sawi, menunjukkan bahwa pertumbuhan tanaman yang lebih tinggi dibandingkan dengan media lainnya. Hal ini berakibat pada hasil bobot sawi basah yang juga lebih tinggi dibandingkan dengan perlakuan lainnya (35,92 g) (Gustia, 2013). Arang sekam bersifat lebih remah dibandingkan dengan cocopeat, sehingga berpengaruh terhadap pertumbuhan akar yang berpengaruh positif terhadap pertumbuhan daun (Irawan \& Kafiar, 2015). 


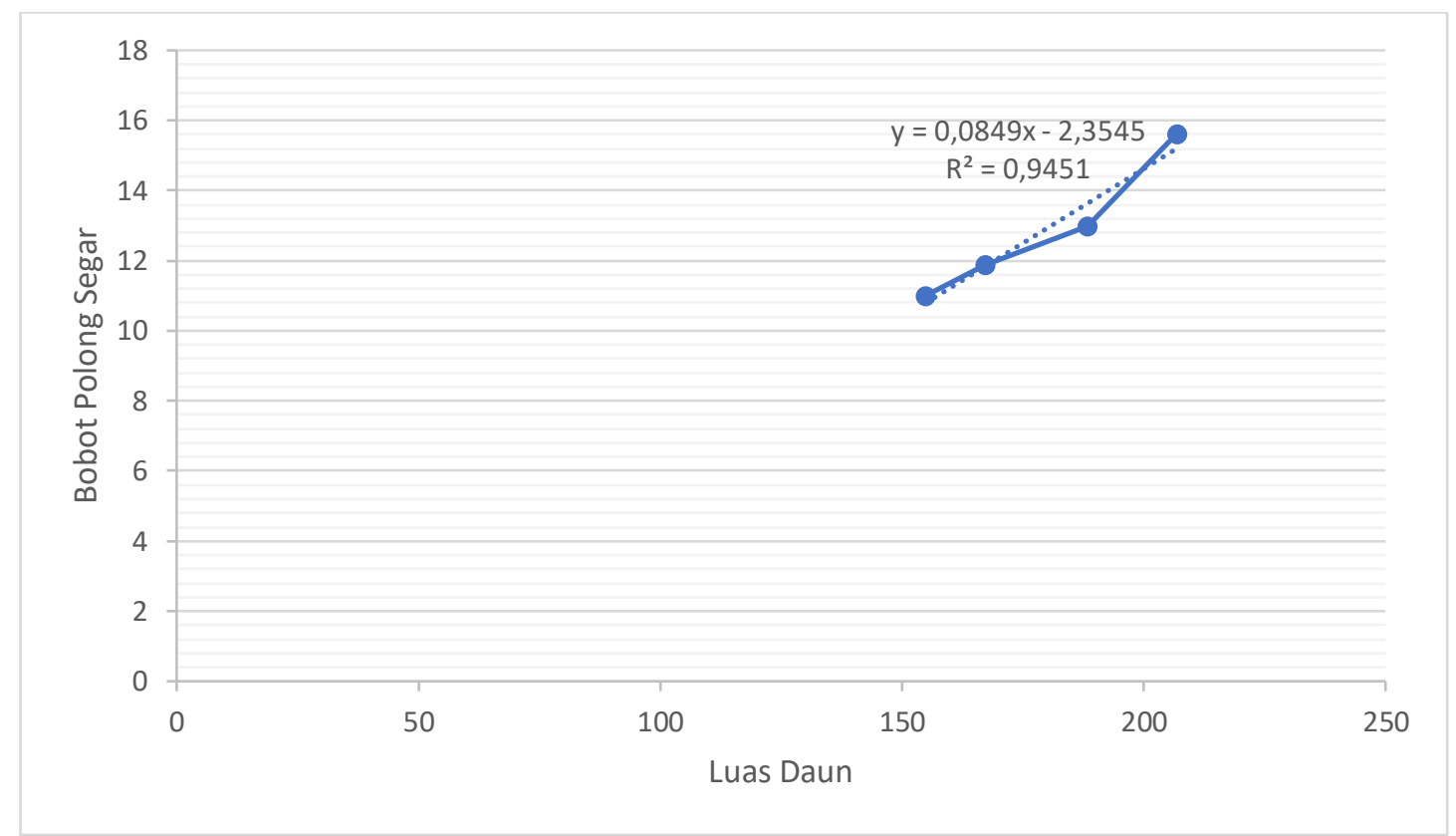

Gambar 2. Grafik Korelasi Linear antara Luas Daun dan Bobot Polong Segar

\section{Bobot Polong Kering}

Tabel 5 menunjukkan bahwa pemberian pupuk guano dengan dosis $15 \mathrm{t}$ ha- 1 dan media tanam tanah+arang sekam memberikan hasil yang terbaik untuk parameter bobot polong kering. Bobot polong kering juga dipengaruhi oleh bobot polong basah. Hasil penelitian ini menunjukkan hasil yang konsisten terhadap parameter hasil tanaman (Tabel 4).

Tabel 5. Pengaruh Pupuk Guano dan Media Tanam Terhadap Bobot Polong Kering

\begin{tabular}{lc}
\hline \multicolumn{1}{c}{ Perlakuan } & Rata-rata Bobot Kering Polong $(\mathrm{g})$ \\
\hline Nafos Guano & \\
$\mathrm{g}_{0}$ (Kontrol) & $0,94 \mathrm{a}$ \\
$\mathrm{g}_{1}$ (Guano $\left.5 \mathrm{t} \mathrm{ha}^{-1}\right)$ & $1,15 \mathrm{~b}$ \\
$\mathrm{~g}_{2}$ (Guano $\left.10 \mathrm{t} \mathrm{ha}^{-1}\right)$ & $1,38 \mathrm{c}$ \\
$\mathrm{g}_{3}$ (Guano $\left.15 \mathrm{t} \mathrm{ha}^{-1}\right)$ & $1,55 \mathrm{~d}$ \\
\hline Media Tanam & \\
$\mathrm{m}_{0}$ (Kontrol) & $1,47 \mathrm{c}$ \\
$\mathrm{m}_{1}$ (Arang sekam padi) & $1,00 \mathrm{a}$ \\
$\mathrm{m}_{2}$ (Cocopeat) & $0,91 \mathrm{a}$ \\
$\mathrm{m}_{3}$ (Tanah+Arang sekam) & $1,60 \mathrm{~d}$ \\
$\mathrm{~m}_{4}$ (Tanah+Cocopeat) & $1,31 \mathrm{~b}$ \\
\hline
\end{tabular}

Keterangan: Angka rata-rata yang diikuti oleh huruf yang sama pada kolom yang sama menunjukkan tidak berbeda nyata berdasarkan Uji Lanjut Duncan pada taraf $5 \%$. 
Pupuk guano dengan dosis $15 \mathrm{t} \mathrm{ha}^{-1}$ mampu menyediakan kebutuhan hara makro dan mikro yang berperan dalam proses fotosintesis serta proses fisiologi yang terjadi dalam tanaman terutama translokasi unsur hara dan hasil fotosintat akan berjalan dengan baik. Unsur hara yang diserap oleh akar yang di translokasikan ke bagian vegetatif tanaman maupun generatif untuk memacu proses fotosintesis secara optimal sehingga dapat mempengaruhi berat kering tanaman (Riyantini et al., 2016).

Berat polong kering mencerminkan akumulasi dari fotosintat yang ditranslokasikan ke bagian polong
(Kurniawan et al., 2017). Unsur hara yang telah diserap oleh akar baik yang digunakan dalam sintesis senyawa organik maupun yang tetap dalam bentuk ionik dalam jaringan tanaman akan memberikan kontribusi terhadap pertambahan berat kering tanaman (Rastono et al., 2018).

Pada penelitian ini, bobot polong kering memiliki kaitan yang erat dengan luas daun dan bobot polong segar. Hal ini ditunjukkan dengan nilai koefisien korelasi antara luas daun dan bobot polong kering, yaitu sebesar 0,99 (Tabel 7) dan hubungannya linear positif (Gambar 3). Nilai ini menunjukkan bahwa besarnya luas daun sangat mempengaruhi bobot polong kering.

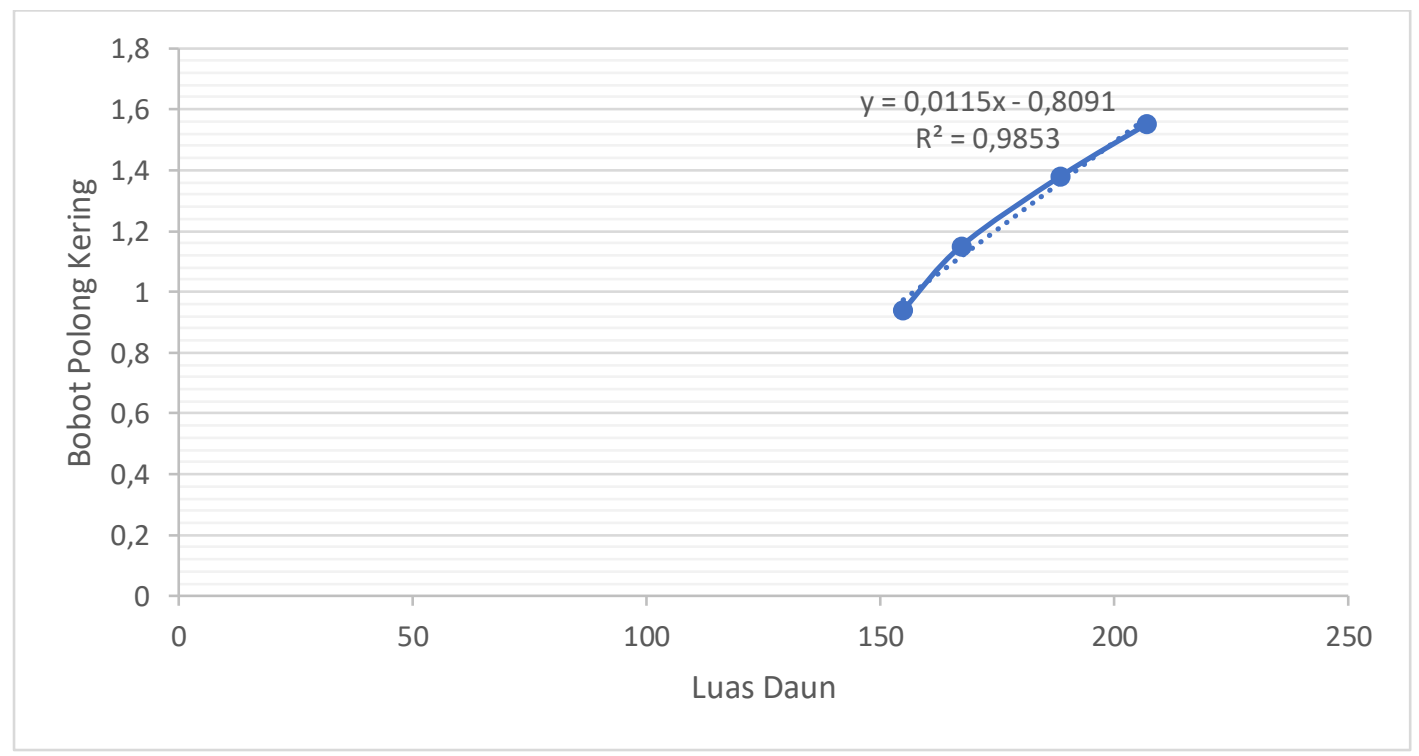

Gambar 2. Grafik Persamaan Linear antara Luas Daun dan Bobot Polong Kering

\section{Indeks Panen}

Tabel 6 menunjukkan bahwa pemberian pupuk guano dengan dosis $15 \mathrm{t} \mathrm{ha}^{-1}$ memberikan pengaruh yang nyata terhadap parameter indeks panen, tetapi media tanam memberikan pengaruh yang tidak nyata. Indeks panen menunjukkan kemampuan tanaman menyalurkan asimilatnya (Kurniawan et al., 2017). Indeks panen menggambarkan seberapa besar efisiensi dari penyaluran hasil fotosintesis (fotosintat) ke bagian buah. Indeks panen juga berkaitan dengan kekuatan sink, dalam hal ini polong, untuk menarik fotosintat (Ernawati et al., 2018). Hasil dari penelitian 
ini menunjukkan bahwa pada pemberian pupuk Nafos Guano dosis $15 \mathrm{t}$ ha- ${ }^{1}$ menghasilkan bobot polong segar dan bobot polong kering tertinggi diantara perlakuan dosis lainnya.

Tabel 6. Pengaruh Pupuk Guano dan Media Tanam Terhadap Indeks Panen

\begin{tabular}{lc}
\hline \multicolumn{1}{c}{ Perlakuan } & Rata-rata Indeks Panen \\
\hline Guano & \\
$\mathrm{g}_{0}$ (Kontrol) & $0,22 \mathrm{a}$ \\
$\mathrm{g}_{1}\left(\right.$ Guano $\left.5 \mathrm{t} \mathrm{ha}^{-1}\right)$ & $0,29 \mathrm{~b}$ \\
$\mathrm{~g}_{2}\left(\right.$ Guano $\left.10 \mathrm{t} \mathrm{ha}^{-1}\right)$ & $0,40 \mathrm{c}$ \\
$\mathrm{g}_{3}\left(\right.$ Guano $\left.15 \mathrm{t} \mathrm{ha}^{-1}\right)$ & $0,43 \mathrm{~d}$ \\
\hline Media Tanam & \\
$\mathrm{m}_{0}$ (Kontrol) & $0,34 \mathrm{a}$ \\
$\mathrm{m}_{1}$ (Arang sekam padi) & $0,32 \mathrm{a}$ \\
$\mathrm{m}_{2}$ (Cocopeat) & $0,31 \mathrm{a}$ \\
$\mathrm{m}_{3}$ (Tanah+Arang sekam) & $0,36 \mathrm{a}$ \\
$\mathrm{m}_{4}$ (Tanah+Cocopeat) & $0,33 \mathrm{a}$ \\
\hline
\end{tabular}

Keterangan: Angka rata-rata yang diikuti oleh huruf yang sama pada kolom yang sama menunjukkan tidak berbeda nyata berdasarkan Uji Lanjut Duncan pada taraf $5 \%$.

\section{Korelasi antara Dosis Pupuk Guano dengan Pertumbuhan Tanaman Buncis}

Hasil penelitian menunjukkan bahwa terdapat korelasi yang erat antara penambahan dosis pupuk guano dengan variabel pertumbuhan. Dosis pupuk $15 \mathrm{tha}^{-}$ 1 menghasilkan tinggi, luas daun, bobot polong segar, bobot polong kering dan indeks panen terbesar dibandingkan dengan dosis lainnya. Hubungan antara dosis guano dengan variabel pertumbuhan juga linear positif, artinya semakin tinggi dosis yang digunakan, maka pertumbuhan tanaman buncis pun akan semakin tinggi (Tabel 7).

Korelasi positif antara dosis pupuk guano dengan pertumbuhan tanaman juga terjadi pada tanaman jagung. Peningkatan dosis pupuk guano berpengaruh positif terhadap tinggi tanaman, jumlah daun, diameter batang, jumlah tongol dan diameter tongkol jagung (Harahap et al., 2018)

\section{SIMPULAN}

Berdasarkan hasil penelitian yang telah dilakukan dapat disimpulkan sebagai berikut

1. Terdapat interaksi antara perlakuan pupuk guano dan media tanam terlihat pada variabel pengamatan tinggi tanaman 28 HST.

2. Secara mandiri dosis pupuk guano $15 \mathrm{t}$ ha $^{-1}$ memberikan hasil yang terbaik untuk semua parameter pengamatan, sedangkan perlakuan media tanam tanah+arang sekam memberikan pengaruh yang baik terhadap parameter tinggi tanaman, bobot segar polong dan bobot kering polong. 
3. Terdapat korelasi positif antara dosis pupuk guano dengan pertumbuhan dan hasil buncis tegak Kenya.

\section{DAFTAR PUSTAKA}

Bintara, A. K. P., Tyasmoro, S. Y., \& Nugroho, A. (2017). Pengaruh kadar kelengasan tanah dan pemberian polimer acrylic pada pertumbuhan anakan tanaman tebu (Saccharum officinarum $\mathrm{L}$ ). Jurnal Produksi Tanaman, 5(5), 704-709. Diambil dari http://protan. studentjournal.ub.ac.id/index.php/pro $\tan /$ article/view/433

Djuariah, D., Rosliani, R., Kurniawan, H., \& Lukman, L. (2016). Seleksi dan Adaptasi Empat Calon Varietas Unggul Buncis Tegak untuk Dataran Medium (Selection and Adaptation of Four Variety Candidates Superior Bush Bean Varieties for Medium Land ). J. Hort, 26(1),49-58.https://doi.org/https:// dx.doi.org/10.21082/jhort.v26n1.2016 .p49-58

Drupadi, C., \& Suhardiyanto, H. (2016). Sifat Thermo-Fisik Arang Sekam. Jurnal Teknotan, 10(2), 1-6. Diambil dari https://jurnal.unpad.ac.id/teknotan/ar ticle/view/10298

Ernawati, W, E. R. P., \& Mukarlina. (2018). Respon Pertumbuhan Vegetatif Tanaman Buncis (Phaseolus vulgaris $\mathrm{L}$ ) Dengan Pemberian Kompos Limbah Kulit Pisang Nipah. Jurnal Protobiont, 7(1), 45-50. $\quad$ https://doi.org/ https://dx.doi.org/10.26418/protobio nt.v7i1.23627

Gustia, H. (2013). Pengaruh penambahan sekam bakar pada media tanam terhadap pertumbuhan dan produksi tanaman sawi (Brassica juncea L.). Journal WIDYA Kesehatan Dan
Lingkungan, 12, 12-17. Diambil dari https://e-journal.jurwidyakop3.com/ index.php/kes-ling/article/view/123

Harahap, D. A., Adiwirman, \& Yulia, A. E. (2018). Pengaruh pupuk guano dan N terhadap pertumbuhan dan produksi tanaman jagung manis (Zea mays saccharata Strurt). JOM FAPERTA, 5(2), 1-15. Diambil dari https://jom.unri.ac.id/index.php/JOM FAPERTA/article/view/22423

Hariyadi. (2018). Respon pertumbuhan tanaman jagung mais (Zea mays L. Saccharata Sturt) terhadap pemberian kotoran atyam dan guano wallet pada tanah gambut pedalaman. https://doi.org/https://doi.org/10.338 30/jmst.v19i2.105.2018

Irawan, A., \& Kafiar, Y. (2015). Pemanfaatan cocopeat dan arang sekam padi sebagai media tanam bibit cempaka wasian (Elmerrilia ovalis). Prosiding Seminar Nasional Masyarakat Biodiversitas Indonesia, 1(4), 805-808. https://doi.org/10.13057/psnmbi/m0 10423

Isrun. (2009). Respons inceptisols terhadap pupuk guano dan pupuk $P$ serta pengaruhnya terhadap serapan $P$ tanaman kacang tanah. Jurnal Agroland, 16(1), 40-44. Diambil dari http://jurnal.untad.ac.id/jurnal/index. php/AGROLAND/article/view

Kurniawan, R. M., Purnamawati, H., \& E.K, Y. W. (2017). Respon Pertumbuhan dan Produksi Kacang Tanah (Arachis hypogaea L.) terhadap Sistem Tanam Alur dan Pemberian Jenis Pupuk. Buletin Agrohorti, 5(3), 342-350. https://doi.org/https://doi.org/10.292 44/agrob.v5i3.16472 
Lakitan, B. (2010). Dasar-Dasar Fisiologi Tumbuhan (1 ed.). Jakarta: PT Raja Grafindo Persada.

Marsha, N. D., Aini, N., \& Sumarni, T. (2014). Pengaruh Frekuensi dan Volume Pemberian Air Pada Pertumbuhan Tanaman Crotalaria mucronata Desv. Jurnal Produksi Tanaman, 2(8), 673$678 . \quad$ Diambil dari http://protan.studentjournal.ub.ac.id/ index.php/protan/article/view/159/15 5

Marsha, N. D., Aini, N., \& Sumarni, T. (2015). Pengaruh frekuensi dan volume pemberian air pada pertumbuhantanaman Crotalaria mucronata Desv. Jurnal Produksi Tanaman, 2(8). https://doi.org/ 10.21176/PROTAN.V218.159

Naben, P., \& Raharjo, T. P. (2017). Pengaruh Takaran Pupuk Guano dan Biochar terhadap Pertumbuhan dan Hasil Tanaman Kacang Merah (Phaseolus vulgaris L.) di Lahan Kering pada Dataran Menengah. In Savana Cendana (Vol. https://doi.org/10.32938/sc.v2i04.128

Rastono, A., Sugiyarto, \& Marsusi. (2018). Pertumbuhan dan Produktivitas Lahan Carica (Carica pubescens) dalam Pola Tanam Tumpangsari dengan Stroberi (Fragaria vesca) dan Loncang (Allium fistulosum L.) di Lereng Gunung Lawu. Jurnal Binawakya, 12(9), 445-450. https://doi.org/https://doi.org/10.337 58/mbi.v12i9.1035

Riyantini, I. P., Sudiarso, \& Tyasmoro, S. Y. (2016). Pengaruh pupuk kandang kambing dan pupuk $\mathrm{KCl}$ terhadap pertumbhuan dan hasil tanaman edamame (Glycine max (L.) Merr.). Jurnal Produksi Tanaman, 4(2), 97-
103. Diambil dari http://protan.studentjournal.ub.ac.id/ index.php/protan/article/view/265

Sari, M. N., Sudarsono, \& Darmawan. (2017). Pengaruh Bahan Organik Terhadap Ketersediaan Fosfor pada Tanah-Tanah Kaya Al dan Fe. Buletin Tanah dan Lahan, 1(1), 65-71. Diambil dari

https://journal.ipb.ac.id/index.php/bt anah/article/view/17693/12667

Sitompul, S. M. (2016). Analisis Pertumbuhan Tanaman (1 ed.; Sitawati \& S. Y. Tyasmoro, Ed.). Malang: UB Press.

Suswati, Indrawati, A., \& Putra, D. P. (2015). Penapisan Limbah Pertanian (Sabut Kelapa dan Arang Sekam) dalam Peningkatan Ketahanan Bibit Pisang Barangan Bermikoriza Terhadap Blood Disease Bacterium Dan Fusarium oxysporum F . Sp . Cubense. J. HPT Tropika, 15(1), 81-88. https://doi.org/https://doi.org/10.239 60/j.hptt.11581-88

Syofiani, R., \& Oktabriana, G. (2017). Aplikasi Pupuk Guano Dalam Meningkatkan Unsur Hara N, P, K, Dan Pertumbuhan Tanaman Kedelai Pada Media Tanam Tailing Tambang Emas. Pertanian dan Tanaman Herbal Berkelanjutan di Indonesia, 98-103. Diambil dari https://jurnal.umj.ac.id/index.php/se mnastan/article/view/2264

Taek, R. (2016). Pengaruh Takaran Arang Sekam dan Guano terhadap Pertumbuhan dan Hasil Kacang Hijau (Vigna radiata L.). Savana Cendana, 1(04), 121-124. https://doi.org/10.32938/sc.v1i04.73 